\title{
COMPOSITIONAL AND STRUCTURAL VARIABILITIES OF MG-RICH IRON OXIDE SPINELS FROM TUFFITE(1)
}

\author{
W. N. MUSSE L (2), J . D. FABRIS ${ }^{(2)}$, J . M. D. COEY(3), \\ L. M. A. SANS ${ }^{(4)} \&$ M. F. F. LELIS ${ }^{(5)}$
}

\begin{abstract}
SUMMARY
Maghemite $\left(\gamma \mathrm{Fe}_{2} \mathrm{O}_{3}\right)$ from tuffite is exceptionally rich in $\mathrm{Mg}$, relatively to most of those reportedly found in other mafic lithosystems. To investigate in detail the compositional and structural variabilities of this natural magnetic iron oxide, sets of crystals were isolated from samples collected at different positions in a tuffite weathering mantle. These sets of crystal were individually powdered and studied by X-ray diffractometry, Mössbauer spectroscopy, magnetization measurements and chemical analysis. Lattice parameter of the cubic cell $\left(a_{0}\right)$ was found to vary from $0.834(1)$ to $0.8412(1) \mathrm{nm}$. Lower $a_{0}$-values are characteristic of maghemite whereas higher ones are related to a magnetite precursor. $\mathrm{FeO}$ content ranges up to 17 mass \% and spontaneous magnetization ranges from 8 to $32 \mathrm{~J} \mathrm{~T}^{-1} \mathrm{~kg}^{-1}$. Zero-field room temperature Mössbauer spectra are rather complex, indicating that the hyperfine field distributions due to $\mathrm{Fe}^{3+}$ and mixed valence $\mathrm{Fe}^{3+2+}$ overlap. The structural variabilities of the $(\mathrm{Mg}, \mathrm{Ti})-$ rich iron oxide spinels is essentially related to the range of chemical composition of its precursor $(\mathrm{Mg}, \mathrm{Ti})$-rich magnetite, and probably to the extent to which it has been oxidized during transformation in soil.
\end{abstract}

Index terms: magnetization, Mössbauer, magnetic soil.

\section{RESUMO: VARIABILIDADES COMPOSICIONAL E ESTRUTURAL DE ÓXIDOS DE FERRO RICOS EM MgDE TUFITO}

A maghemita $\left(\mathrm{Fe}_{2} \mathrm{O}_{3}\right)$ detufito é, excepcional mente, rica em magnésio, se comparada às comumente encontradas em outros litossi stemas máficos. Na tentativa deinvestigar em detal hes a variabilidades composicional eestrutural desses óxidos naturais deferro, al guns

\footnotetext{
(1) Recebido para publicação em setembro de 1998 e aprovado em agosto de 1999.

(2) Professor do Departamento de Química, ICEx, Universidade Federal de Minas Gerais - UFMG. CEP $31270-901$ Belo Horizonte (MG)

(3) Professor do Department of Physics, Trinity College, University of Dublin, Dublin 2, Ireland.

(4) Pesquisador da Embrapa Milho e Sorgo. CEP 35701-970 Sete Lagoas (MG).

(5) Professora do Departamento de Química, UFES. CEP 29069-900 Vitória (ES).
} 
conjuntos de cristais foram separados de amostras coletadas a diferentes posições de um manto de intemperismo de tufito. Esses conjuntos de cristais foram, individualmente, estudados por difração de raios-X, espectroscopia Mössbauer, medidas de magnetização e análisequími ca. Da di fratometria deraios-X, observou-sequeo parâmetro da célul a cúbica $\left(a_{0}\right)$ varia de $0,834(1)$ a $0,8412(1) \mathrm{nm}$. Os valores mais baixos de $\mathrm{a}_{0}$ são característicos de maghemita; os mais altos são atribuídos à magnetita, mineral magnético precursor. Os teores de $\mathrm{F} e \mathrm{O}$ al cançam 17 mass \% e os val ores demagnetização espontânea variam de 8 a $32 \mathrm{~J} \mathrm{~T}^{-1} \mathrm{~kg}^{-1}$. Os espectros Mössbauer, obtidos com a amostra mantida à temperatura do ambiente, na ausência decampo magnético apl icado, são bastantecomplexos, com indicações de ocorrência desuperposição de distribui ções decampo hiperfino, devidas ao $\mathrm{Fe}^{3+}$ eao íon devalência mista $\mathrm{Fe}^{3+2+2+}$. A variabilidade estrutural dos óxidos deferro, isoestruturais ao espinélio ericos em MgeTi, é, essencial mente, relacionada com os graus variáveis deoxi dação do mineral precursor, a magnetita rica em Mg eTi.

Termos deindexação: magnetização, Mössbauer, solos magnéticos.

\section{INTRODUCTION}

A (Mg, Ti)-rich maghemite from tuffite, a mafic rock formed from volcanic ashes from the Alto Paranaíba region, in Minas Gerais, Brazil, was earlier identified (Fabris et al., 1994) and characterized (Fabris et al., 1995). Goulart et al. (1997) have shown evidences of multiple spinel phases in a soil developing on tuffite of that same area, with different chemical compositions and unit cell dimensions determined from the (440)-reflection. One of these phases had a similar composition to the $(\mathrm{Mg}, \mathrm{Ti})$-rich maghemite described by Fabris et al. (1995). It was later suggested that structural iron in the inner phase of some grains of iron rich spinel from tuffite had a ferrous character (Fabris et al., 1997). Whether thestructural heterogeneity of such iron oxide spinels is of a wider spatial occurrence than that reported in single-sample studies (F abris et al., 1997; Goulart et al., 1997) in that system was no clear at that time.

The purpose of this work was to examine ironrich spinel phases from samples collected at various depths in a weathering mantle of tuffite in the Alto Paranaíba region, to investigate, in more detail, a large number of samples, in an attempt to provide more data allowing to form a broader and more general picture of their compositional and structural variabilities.

\section{EXPER IMENTAL METHODS}

Thetuffite deposit is approximately $100 \mathrm{~m}$ thick, over Bauru sandstone in the Cretaceous Mata da Corda F ormation. It is a pyroclastic material derived from a long-extinct volcanic source and covers an area of about $5000 \mathrm{~km}^{2}$. The greenish-grey tuffite mantle was exposed in a road-cut of the BR 365 highway, $23.5 \mathrm{~km}$ north of Patos de Minas, Minas Gerais, in the Central Plateau of Brazil. It is overlain by a $6 \mathrm{~m}$ deep Dusky Red Oxisol, which is strongly magnetic (Carmo et al., 1984; Curi, 1984; Ferreira et al., 1994).

The tuffite is porous and friable. It is easily reduced to a powder composed of micron-sized grains. Five samples were collected at depths of 4, 6 , 10, 12 and $14 \mathrm{~m}$ from the top of the mantle. The $4 \mathrm{~m}$ sample corresponds to the B horizon of the Oxisol; the others are materials from the parent rock. The samples were gently crushed in a non-magnetic steel mortar. The powdered material was left in a teflon beaker with $5 \mathrm{~mol} \mathrm{~L}^{-1} \mathrm{NaOH}$ at room temperature for $24 \mathrm{~h}$, under stirring in a magnetic stirrer. The residual solid portions were then washed and black magnetic particles were picked up with a hand magnet. Only the magnetic fractions were kept for further analyses. Submillimeter crystals exhibiting an octahedral habit were then collected from the magnetic separates under a binocular lens. Sets of some tens of crystals were then analyzed for their chemical composition, and by powder X-ray diffractometry, magnetometry and Mössbauer measurements.

Chemical analysis was performed according to standard methods described by J effery \& Hutchison (1981). The sample materials were brought into solution by grinding about $10-20 \mathrm{mg}$ of crystals and dissolving the powder with hydrochloricacid 1:1. The $\mathrm{Fe}^{2+}$ was determined by dissolving separate samples in concentrated $\mathrm{HCl}$ in a $\mathrm{CO}_{2}$ atmosphere. Total $\mathrm{Al}$, $\mathrm{Ca}, \mathrm{Cr}, \mathrm{Fe}, \mathrm{Li}, \mathrm{Mg}, \mathrm{Ni}$, Si and Ti, and minor el ements, namely $\mathrm{As}, \mathrm{Cu}, \mathrm{Hg}, \mathrm{K}, \mathrm{Mn}, \mathrm{Mo}, \mathrm{Na}$ and $\mathrm{Zn}$, were analyzed in a Shimadzu plasma emission spectrophotometer model ICPQ-1014. The Ca2+ was determined in a Perkin-Elmer absorption spectrophotometer model 3300; $\mathrm{Na}^{+}$and $\mathrm{K}+$ were 
determined in a Micronal flame photometer model B262. The averaged compositions in mass \% are presented in Table 1. Polished sections of selected crystals, mounted in a Buehler Transoptic powder resin and covered with a thin carbon layer, were probed with a J eol 733 scanning electron microscope, equipped with an energy-dispersive X-ray spectrometer.

The powder X-ray diffraction (XRD) pattern was obtained with a Siemmens D500 powder diffractometer, using graphite monochromator, CuKa radiation and $0.05^{\circ} 2 \theta / \mathrm{min}$ of step scanning under $40 \mathrm{KV}$ at $40 \mathrm{~mA}$ of vol tage and current, respectively. Silicon was used as an external standard. Optical micropetrographical analyses were performed on polished sections of some crystals, under polarized light.

The spontaneous magnetization was obtained with a compact vibrating sample magnetometer conceived by Cugat et al. (1994). Mössbauer spectra were recorded in a conventional constant acceleration transmission spectrometer and a $\mathrm{Co}$ 57/ $\mathrm{Rh}$ source, at room temperature and $80 \mathrm{~K}$. ACsusceptibility was measured with a conventional vibrating Oxford susceptometer, the sample being submitted to varying temperatures from $77 \mathrm{~K}$ up to $280 \mathrm{~K}$, under a magnetic field of 1 oersted in a frequency of $3000 \mathrm{~Hz}$.

\section{RESULTS AND DISCUSSION}

\section{X-ray measurements}

The X-ray patterns (Figure 1 ) reveal a large structural variabilities of theiron-spinel throughout the mantle, confirming, now in more detail, previously reported evidence of multiple spinel structures in soil developing on tuffite (Goulart et al., 1997), and in its parent material (Fabris et al., 1997). Diagnostic reflections of the spinel phases are split, in the present case, in all samples. No characteristicline due to superstructure is observed for maghemite. Twogroups of thecubiccell dimensions can be identified from this data (Figure 1). In one group, with higher unit cell-dimensions, $\mathrm{a}_{0}$ ranges from $0.8397 \mathrm{~nm}$ up to $0.8412 \mathrm{~nm}$; in the other, $\mathrm{a}_{0}$ ranges from $0.834 \mathrm{~nm}$ up to $0.838 \mathrm{~nm}$. Actually, the reported lattice parameter $a_{0}=0.8417 \mathrm{~nm}$ for the $\mathrm{Fe}^{2+-}$ containing soil iron-spinel from Goulart et al. (1997) is significantly higher than the characteristic $\mathrm{a}_{0}=0.8380$ (2) nm of the fully oxidized ( $\mathrm{Mg}, \mathrm{Ti}$ )-rich maghemite (Fabris et al., 1995) from the parent tuffite. A further study by Fabris et al. (1997) on a set of crystals of the iron-spinel from this tuffite revealed an $\mathrm{Fe}^{2+}$ content of up to 13 mass \%. The powder X-ray analysis also indicated that two spinel phases coexist in the sample: one with higher

Table 1. Chemical composition of a set of crystals according to the sampling depth in the weathering mantle. The numbers in parentheses are uncertainties over the last significant digit estimated as mean standard deviations of independent determinations from three aliquots

\begin{tabular}{|c|c|c|c|c|c|}
\hline \multirow{2}{*}{$\begin{array}{l}\text { Chemical } \\
\text { composition }\end{array}$} & \multicolumn{5}{|c|}{ Sampling depth $(\mathrm{m})$} \\
\hline & 4 & 6 & 10 & 12 & 14 \\
\hline & \multicolumn{5}{|c|}{ mass \% } \\
\hline $\begin{array}{l}\mathrm{Fe}_{2} \mathrm{O}_{3} \\
\mathrm{FeO} \\
\mathrm{TiO}_{2} \\
\mathrm{MgO} \\
\mathrm{Al}_{2} \mathrm{O}_{3} \\
\mathrm{CaO} \\
\mathrm{K}_{2} \mathrm{O} \\
\mathrm{SiO}_{2} \\
\mathrm{MnO} \mathrm{ZnO} \\
\mathrm{Cr}_{2} \mathrm{O}_{3} \\
\mathrm{Na}_{2} \mathrm{O}\end{array}$ & $\begin{array}{r}57(2) \\
7.9(7) \\
13(4) \\
6.5(3) \\
2.4(4) \\
2.5(2) \\
(-) \\
4.1(2) \\
1.5(4) \\
1.5(4) \\
0.25(5) \\
2.6(5)\end{array}$ & $\begin{array}{r}62(1) \\
11.28(9) \\
12(2) \\
6(3) \\
3.5(6) \\
0.9(2) \\
0.8(2) \\
0.6(2) \\
1.5(4) \\
0.6(2) \\
0.6(2) \\
1.4(4)\end{array}$ & $\begin{array}{r}52(2) \\
16.9(7) \\
14.3(8) \\
9(2) \\
2(2) \\
1.1(4) \\
(-) \\
0.36(3) \\
1.5(4) \\
2.1(6) \\
(-) \\
(-)\end{array}$ & $\begin{array}{r}52(2) \\
12.9(4) \\
12.7(4) \\
8(2) \\
3(1) \\
0.81(9) \\
(-) \\
(-) \\
2.0(2) \\
3(2) \\
1.0(6) \\
5(1)\end{array}$ & $\begin{array}{r}55(4) \\
15.5(9) \\
12.5(5) \\
4.7(3) \\
6(3) \\
1.3(4) \\
0.5(5) \\
0.86(9) \\
1.58(9) \\
1.08(9) \\
(-) \\
1.4(4)\end{array}$ \\
\hline \multirow[t]{2}{*}{ Total } & $99(5)$ & $101(4)$ & $99(4)$ & $100(4)$ & $100(5)$ \\
\hline & \multicolumn{5}{|c|}{$\mathrm{mg} \mathrm{kg}^{-1}$} \\
\hline $\begin{array}{l}\text { As } \\
\mathrm{Cu} \\
\mathrm{Hg} \\
\mathrm{MO}\end{array}$ & $\begin{array}{l}146 \\
235 \\
107 \\
100\end{array}$ & $\begin{array}{r}10 \\
96 \\
144 \\
82\end{array}$ & $\begin{array}{r}(-) \\
(-) \\
115 \\
92\end{array}$ & $\begin{array}{l}148 \\
164 \\
140 \\
124\end{array}$ & $\begin{array}{r}41 \\
99 \\
106 \\
89\end{array}$ \\
\hline \multicolumn{6}{|c|}{ Individual masses of aliquots of crystals/mg } \\
\hline $\begin{array}{l}\text { Aliquot } 1 \\
\text { Aliquot } 2 \\
\text { Aliquot } 3\end{array}$ & $\begin{array}{l}20.2 \\
20.5 \\
20.9\end{array}$ & $\begin{array}{l}12.3 \\
12.8 \\
13.5\end{array}$ & $\begin{array}{r}9.6 \\
10.2 \\
15.6\end{array}$ & $\begin{array}{l}10.9 \\
11.2 \\
11.4\end{array}$ & $\begin{array}{l}10.2 \\
10.4 \\
10.6\end{array}$ \\
\hline
\end{tabular}

(-) means that any eventual presence of the element in the sample is in a content below the detection limit of the corresponding method of chemical analysis. 


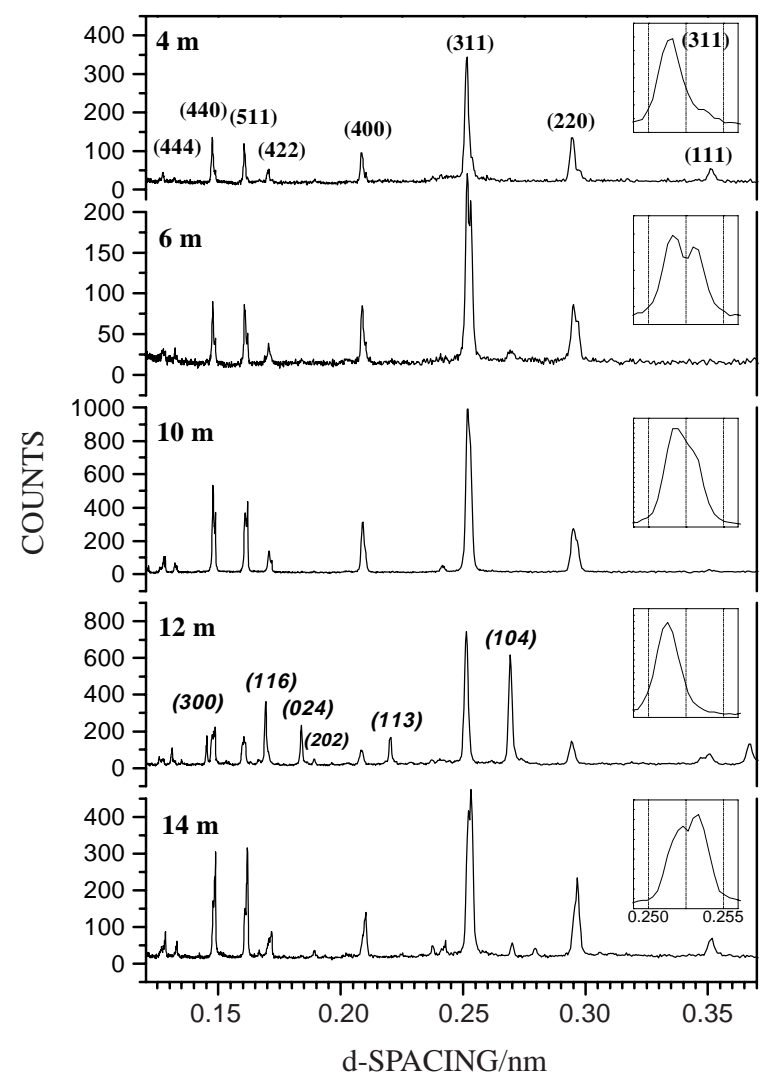

Figure 1. X-ray patterns of powdered crystals under analysis. Reflection planes of cubic iron-spinel are indicated for the $\mathbf{4} \mathrm{m}$ sample and of the hematite for the $12 \mathrm{~m}$ sample (in italics). Inset: a magnified d-spacing scale view of the (311) reflection of the spinel phase is presented for each sample.

$a_{0}$-value of the cubic unit cell, corresponding to a $(\mathrm{Mg}, \mathrm{Ti})$-rich magnetite, and the other with $\mathrm{a}_{0}$ closer to the reported value for $(\mathrm{Mg}, \mathrm{Ti})$-rich maghemite, by Fabris et al. (1995).

Only the higher $\mathrm{a}_{0}$-value spinels (assigned to the magnetite precursor) of the present two groups is fairly (within 10\% probability level) correlated (linear correlation coefficient, $r=0.73$ ) with the sampling depth, taken from thetop of the weathering mantle (see Figure 2, for a qualitative view).

The relative XRD intensities of the (311) split reflections in all samples vary asystematically: the $14 \mathrm{~m}$ sample has the component at highest $\mathrm{d}_{(311)^{-}}$ spacing more intense than for all the other samples (insets, Figure 1). In the 4 and 12 m samples, only a peak asymmetry is actually observed. More intense XRD reflections due to hematite in the $12 \mathrm{~m}$ sample (Figure 1) are explained by the exsolution veins of anisotropic oxide in the iron spinel matrix, as can be seen on the optical micropetrographic image (Figure 3d).

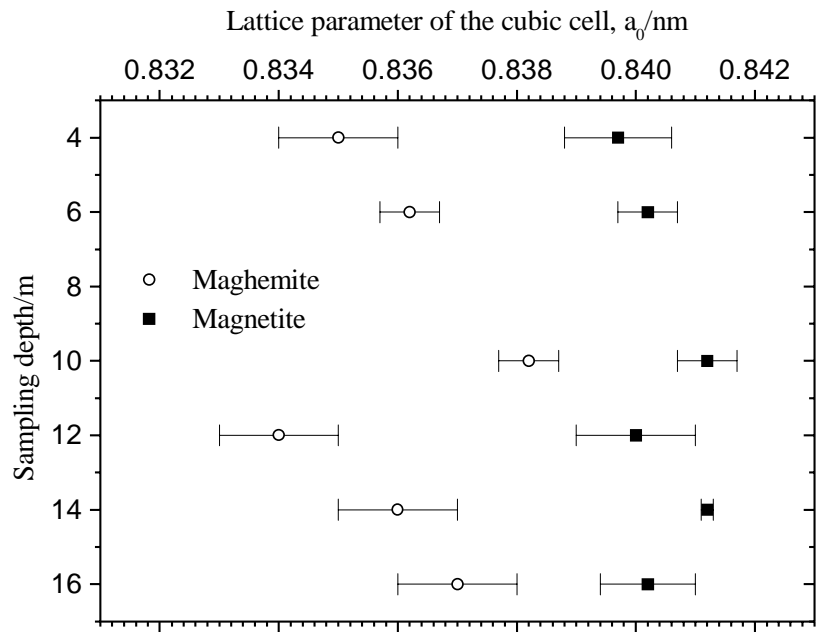

Figure 2. Lattice parameters of cubic cell of the iron-spinel. Two a-dimension values were determined in each sample, based on the split reflections of the powder X-ray patterns.

\section{Optical micropetrographical analysis}

It indicates that hematite actually appears as an exsolution in the spinel matrix (Figure $3 \mathrm{~d}$ ). A complex pattern appears for sample $4 \mathrm{~m}$ (Figure 3a). Based on XRD data (F igure 1 ) most of theiron oxide spinel phase is maghemite, with $a_{0}=0.835 \mathrm{~nm}$. The 6 m sample (F igure $3 \mathrm{~b}$ ) shows two different patterns: one anisotropic zone assignable to ilmentite, with averaged composition from microprobe analysis $\left(\mathrm{M}=152.36 \mathrm{~g} \mathrm{~mol}^{-1}\right)$

$$
\mathrm{Fe}_{0.99}^{2+} \mathrm{Ti}_{0.99}^{4+} \mathrm{Mn}_{0.03}^{2+} \mathrm{O}_{3}
$$

and one isotropic, for which the following nearly pure maghemite formula may be allocated ( $\mathrm{M}=$ $\left.211.96 \mathrm{~g} \mathrm{~mol}^{-1}\right)$ :

$$
\mathrm{Fe}_{2.63}^{3+} \mathrm{Cr}_{0.01}^{3+} \mathrm{Si}_{0.02}^{4+} \otimes_{0.34} \mathrm{O}_{4}
$$

where $\otimes$ is a cation vacancy.

In two samples, collected at $10 \mathrm{~m}$ (Figure 3c), and $14 \mathrm{~m}$ (Figure $3 \mathrm{e}$ ), more than one alteration zone is present (labeled A, B and C), with a clearly distinguishable homogeneous inner core and an altered outer layer, both isotropic under polarized light. A subtleintermediatezoneappears in the $14 \mathrm{~m}$ crystals (Figure 3e); zonelabelled B). Both samples are rich in $\mathrm{Fe}^{2+}($ Table 1$)$. TheSE M probed crystal of the $10 \mathrm{~m}$ (Figure $3 \mathrm{~d}$ ) has a relatively large homogeneous core surrounded by a thin al tered area. If all $\mathrm{Fe}^{2+}+\mathrm{ions}$ are assumed to be located in the core spinel, a more preserved phase, the microprobe analysis over the inner part of a polished section of a typical $10 \mathrm{~m}$ crystal (Figure 3) leads to the averaged formulae (3), $M=206.03 \mathrm{~g} \mathrm{~mol}^{-1}$ (the indexes, as in all formulae presently allocated, were 
calculated from an average of elemental contents from determinations of three different points in the probed matrix):

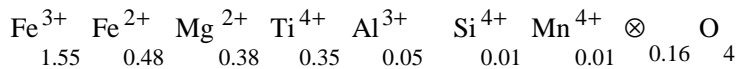

The external layer of this same sample has a composition corresponding to the formula of an assumed fully oxidized maghemite ( $\mathrm{M}=$ $\left.194.49 \mathrm{~g} \mathrm{~mol}^{-1}\right)$ :

$$
\mathrm{Fe}_{1.74}^{3+} \mathrm{Mg}_{0.41}^{2+} \mathrm{Ti}_{0.41}{ }^{4+} \mathrm{Al}_{0.08}^{3+} \mathrm{Si}_{0.01}^{4+} \mathrm{Mn}_{0.01}^{4+} \otimes_{0.33} \mathrm{O}_{4} \text { (4) }
$$

(a)

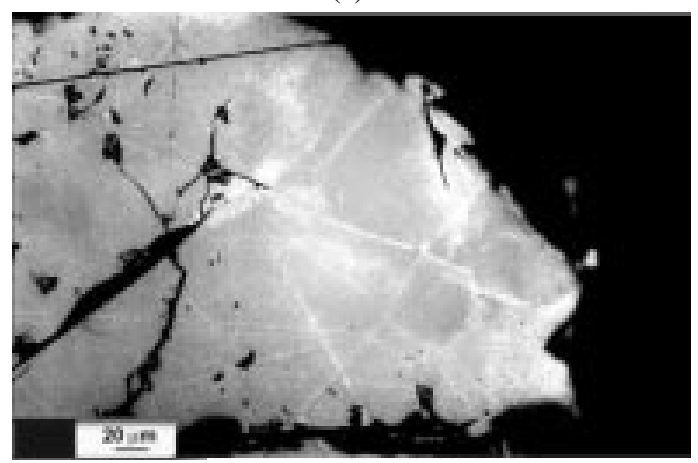

(c)

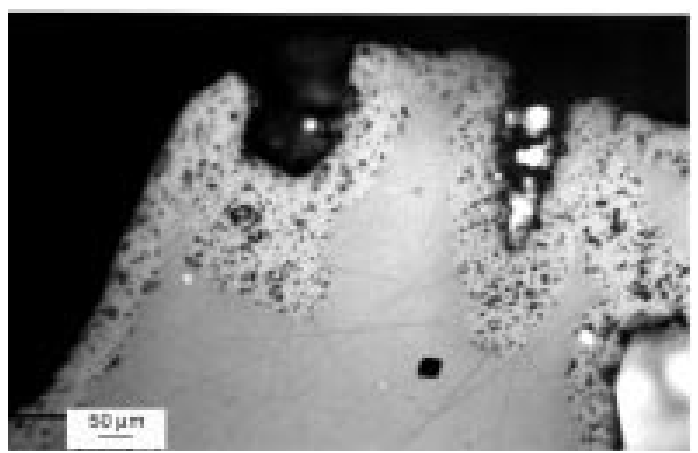

F ormula (4) is comparable to that of the ( $\mathrm{Mg}, \mathrm{Ti})$ rich maghemite identified from a high gradient magnetic separate from tuffite, by Fabris et al. (1995):

$$
\mathrm{Fe}_{1.84}{ }^{3+} \mathrm{Mg}_{0.41}^{2+} \mathrm{Ti}_{0.32}^{4+} \mathrm{Al}_{0.07}^{3+} \mathrm{Cr}_{0.03}^{3+} \mathrm{Mn}_{0.02}^{4+} \mathrm{Si}_{0.01}^{4+} \otimes_{0.30} \mathrm{O}_{4}
$$

with $\mathrm{M}=196.88 \mathrm{~g} \mathrm{~mol}^{-1}$.

The Fe2+-rich spinel (3) corresponds to a highly ( $\mathrm{Mg}, \mathrm{Ti}$ )-substituted magnetitewith thehighest cubic unit cell dimension $\left(a_{0}=0.8412 \mathrm{~nm}\right)$ and spontaneous magnetization $\left(\sigma_{\mathrm{s}} \sim 32 \mathrm{~J} \mathrm{~T}^{-1} \mathrm{~kg}^{-1}\right)$, (b)

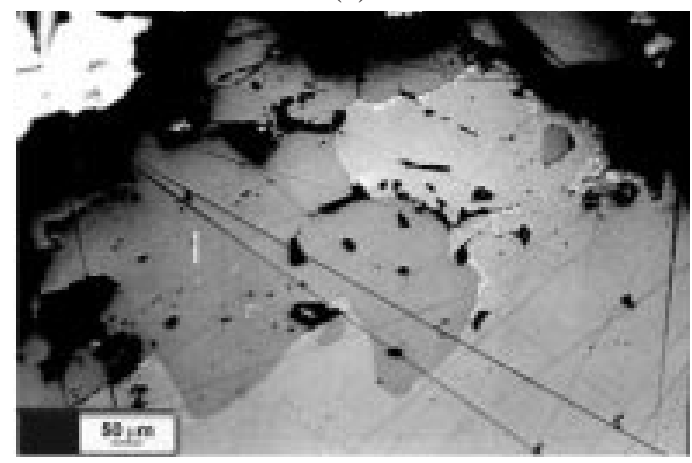

(d)

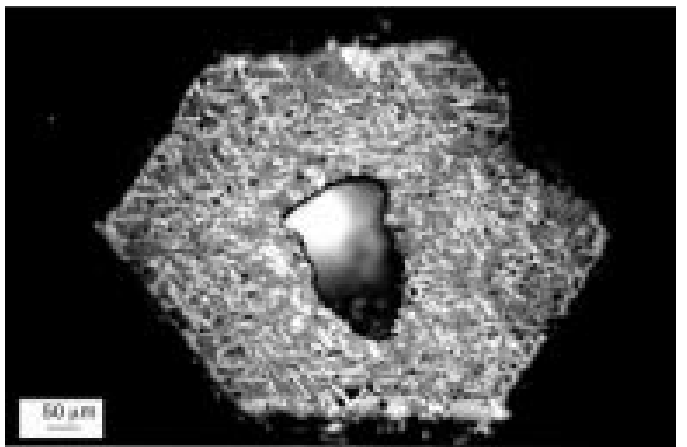

(e)

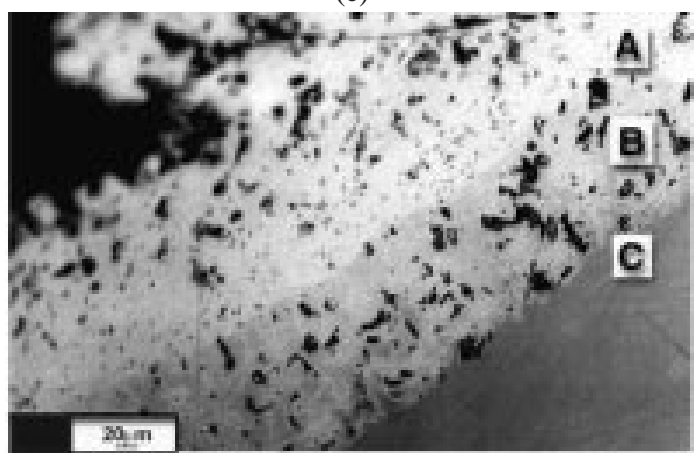

Figure 3. Optical micrographs, taken under a petrographical microscope with polarized light, of polished sections of crystals separated from samples collected from a tuffite mantle, at depths of (a) 4 m, with exsolution of hematite; (b) $6 \mathrm{~m}$, with presence of ilmenite; (c) $10 \mathrm{~m}$, with two alteration zones, an inner core and an oxidized external layer; (d) $12 \mathrm{~m}$, presenting exsolution of hematite, along with inclusions of ilmenite and (e) $\mathbf{1 4}$ m, showing three alteration zones labeled A, B and C. 
among all spinel phases being presently studied. This is very likely an igneous precursor of the ( $\mathrm{Mg}, \mathrm{Ti})$ rich maghemite of tuffite. These arguments are reinforced by optical micropetrographic analysis, that shows characteristic features of magnetite in the core and of maghemite in the outer layer (Figure 3c).

The existence of an intermediatealteration zone in the $14 \mathrm{~m}$ sample (Figure 3, labelled B) does not al low to unambiguously allocateall $\mathrm{Fe}^{2+}$, determined by conventional chemical analysis of the set of crystals (Table 1 ), to the inner phase. If all iron is simply allocated as $\mathrm{Fe}^{3+}$ in this phase, the following formula is obtained ( $\mathrm{M}=197.89 \mathrm{~g} \mathrm{~mol}-1)$ :

$$
\mathrm{Fe}^{3+} \mathrm{Mg}^{2+} \mathrm{Ti}^{4+} \mathrm{Al}^{3+} \mathrm{Si}^{4+} \mathrm{Mn}^{4+} \otimes \mathrm{O}_{4}
$$

With a similar approach, the compositions of the intermediate ((7), $\left.M=197.77 \mathrm{~g} \mathrm{~mol}^{-1}\right)$ and the external layers ((8), $M=196.80 \mathrm{~g} \mathrm{~mol}^{-1}$ ) correspond to:

$$
\begin{array}{ccccccccc}
\mathrm{Fe}^{3+} & \mathrm{Mg}^{2+} & \mathrm{Ti}^{4+} & \mathrm{Al}^{3+} & \mathrm{Si}^{4+} & \mathrm{Mn}^{4+} & \otimes & \mathrm{O}_{4}
\end{array}
$$

and

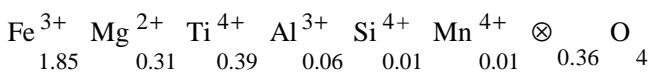

The decreasing iron content (expressed in formulae (6) through (8) exclusively as $\mathrm{Fe}^{3+}$ ) from theinner to the outer part of this crystal means that Fe (and also $\mathrm{Mg}^{2+}$ ) is progressively lost from the lattice during the oxidation process, from the core to the external layer. The relative amount of $\mathrm{Ti}^{4+}$ increases in the same direction. The formula (6) is comparable to the core phase composition (9) reported by Goulart et al. (1997), for a spinel grain from a soil derived from tuffite of the same area, in which all iron content was allocated in its higher oxidation state (the numbers in brackets following the formula indexes were originally estimated uncertainties over the last significant digit, taken as standard deviations from the mean of corresponding probed points):

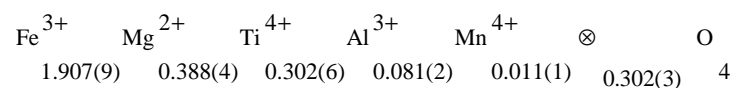

\section{Magnetization}

Magnetization curves at room temperature (Figure 4) indicatean approach to saturation at a field of $\sim 0.2$ tesla in all samples, but spontaneous magnetization varies from $\sigma_{\mathrm{s}}-8 \mathrm{~J} \mathrm{~T}^{-1} \mathrm{~kg}^{-1}(12 \mathrm{~m})$ to $\sigma_{\mathrm{s}} \sim 32 \mathrm{~J} \mathrm{~T}^{-1} \mathrm{~kg}^{-1}(10 \mathrm{~m})$. From chemical analysis (Table 1), these iron oxide samples are rich in structural ( $\mathrm{Ti}, \mathrm{Mg}$ ) and contain some Al, which can help explain the lower $\sigma_{\mathrm{s}}$-values relative to the pure maghemite $\left(-60 \mathrm{~J} \mathrm{~T}^{-1} \mathrm{~kg}^{-1}\right)$ or magnetite $\left(100 \mathrm{~J} \mathrm{~T}^{-1} \mathrm{~kg}^{-1}\right)$.

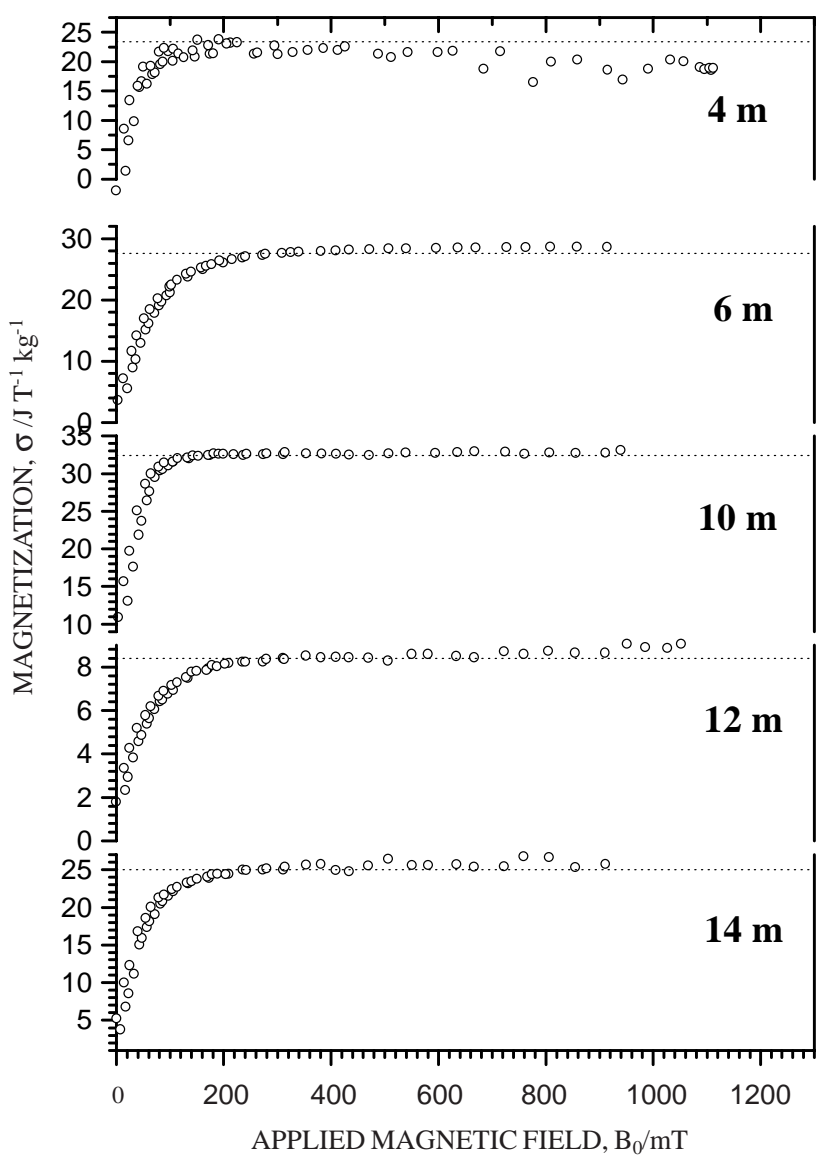

Figure 4. Magnetization measurement obtained from a selected single crystal of each sample group. Dotted straight lines represent linear reggressions comprising points of the plateau approaching saturation.

I somorphical substituent $\mathrm{Mg}^{2+}$ ions reduced saturation magnetization as lattice incorporation. For instance, the saturation magnetization at $4.2 \mathrm{~K}$, under an applied magnetic field of 5 tesla, in synthetically $\mathrm{Mg}$-doped maghemites drops from 78 J T-1 $\mathrm{kg}^{-1}$ (pure, $\mathrm{Fe}^{3+}{ }_{2,67} \otimes_{0.33} \mathrm{O}_{4}$ ) down to $25 \mathrm{~J} \mathrm{~T}^{-1} \mathrm{~kg}^{-1}$ $\mathrm{Fe}^{3+}{ }_{2,12} \mathrm{Mg}^{2+}{ }_{0.81} \otimes_{0.06} \mathrm{O}_{4}$ ) (Mussel et al., 1997).

\section{Magnetic susceptibility measurements}

The magnetic behavior as a function of temperature is markedly different, from sample to sample. Magnetic susceptibility (expressed as voltagesignal, Figure 5) of a crystal from the sample collected at $14 \mathrm{~m}$ exhibits a sharp increase at $131.8 \mathrm{~K}$, which is dueto the Verwey phasetransition in magnetite. A comparative measurement of the magnetic susceptibility of a single crystal of a natural stoichiometric magnetite is also presented in Figure 5, for which $T_{V} \sim 115.1 \mathrm{~K}$. For all the other samples no such a clear transition can be observed. 


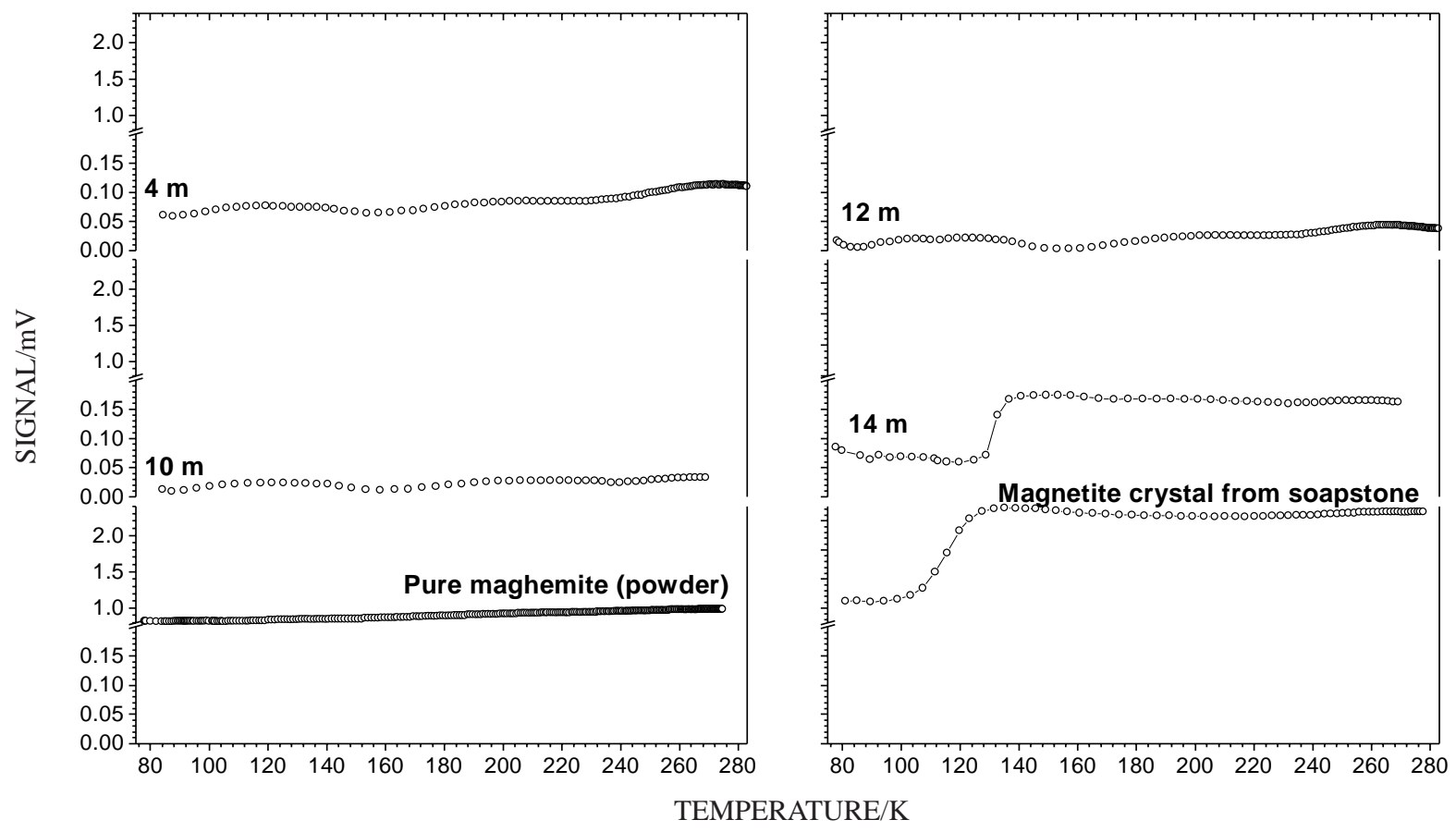

Figure 5. Magnetic susceptibility curves, expressed as electrical signal amplitude, of a selected single crystal of each sample. Pure synthetic maghemite (powder) and a crystal of magnetite from soapstone are also presented, for comparison.

\section{Mössbauer}

Mössbauer spectra of all samples, both at $298 \mathrm{~K}$ and $80 \mathrm{~K}$ are rather complex (Figure 6). Leastsquare fitting of these spectra requires a number of constrained parameters, which makes thenumerical analysis somewhat artificial. Unless experimental refinements could be made, as by measuring with a strong (>5 T) external magneticfield, nosubspectral separation is unequivocally obtained. For this reason, the Mössbauer analysis here is qualitative. In spectra at $298 \mathrm{~K}$, two features can be cited: the unequal intensities and widths of lines 1 (leftmost) and 6 (rightmost). F or the $4 \mathrm{~m}$ sample, line 1 is more intense and narrower than line 6 , whereas the inverse is observed for all other samples. In $10 \mathrm{~m}$ sample, line 1 presents an asymmetric shape with a right-side shoulder, suggesting that some high spin $\mathrm{Fe}^{2+}$ contributes to the total resonance absorption. From X-ray analysis, the $\mathrm{Fe}^{2+}$ would be very probably due to the presence of magnetite. This assignment was used by Fabris et al. (1997) to interpret the Mössbauer spectrum of these samples. In the $4 \mathrm{~m}$ sample, the spectral shape is more characteristic of $\mathrm{Fe}^{3+}$ in both sites of the dominant maghemite structure.

The $\mathrm{e}^{2+-}$ richer spinel phase is assumed to bethe more preserved precursor of the ( $\mathrm{Mg}, \mathrm{Ti})$-rich maghemite, in the iron-rich phase assemblage. If so, the structural variabilities of the $(\mathrm{Mg}, \mathrm{Ti})$-rich

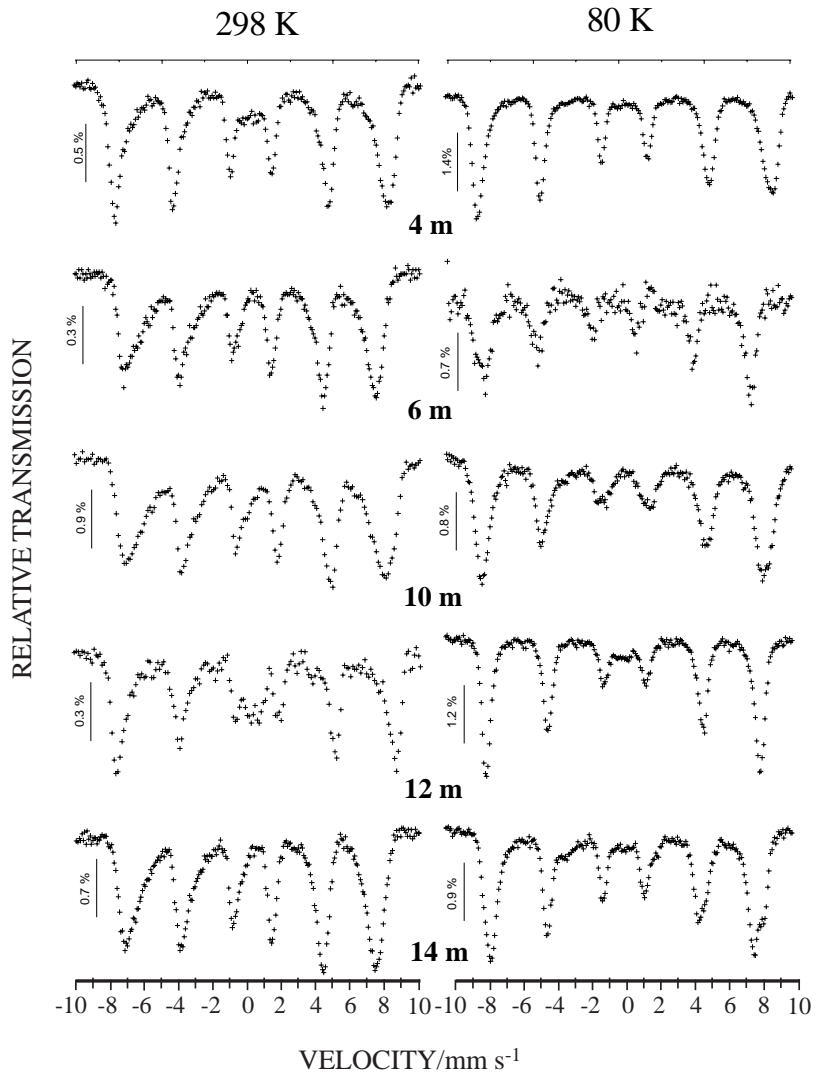

Figure 6. $298 \mathrm{~K}$ and $80 \mathrm{~K}$ Mössbauer spectra of powdered magnetic crystals. 
maghemite is essentially related to the wide range of composition and cubic unit cell dimension of its precursor, (Mg, Ti)-rich magnetite, though the subsequent role played by fundamental weathering processes, involved in the $\mathrm{Fe}^{2+}$ oxidation during pedogenesis, can not be separately identified.

\section{CONCLUSIONS}

As far as the lattice parameter of the cubic cell $\left(a_{0}\right)$ is concerned, two groups can be identified from XRD data: one of them with higher $\mathrm{a}_{0}$-dimensions, ranging from 0.8397 to $0.8412 \mathrm{~nm}$, and the other with lower $\mathrm{a}_{0}$-values, from 0.834 to $0.838 \mathrm{~nm}$. The first group can be related to an $\mathrm{Fe}^{2+-}$-richer spinel and is assumed to be the igneous precursor of the second, which has unit cell dimensions closer to that of $(\mathrm{Mg}, \mathrm{Ti})$-rich maghemite. $\mathrm{FeO}$ contents from chemical analysis range up to 17 mass \% and spontaneous magnetization $\sigma_{\mathrm{s}}=8$ to $32 \mathrm{~J} \mathrm{~T}^{-1} \mathrm{~kg}^{-1}$. Zero-fiel d room temperature Mössbauer spectra are rather complex, indicating that, the hyperfine field distributions due to $\mathrm{Fe}^{3+}$ and mixed valence $\mathrm{Fe}^{3+/ 2+}$ overlap, producing very broad and asymmetric resonance lines. Only a qualitative Mössbauer analysis is actually provided, as the excessive number of parameter constrains, required to fit those spectra, gives very artificial results. The structural variabilities of the ( $\mathrm{Mg}, \mathrm{Ti})$ rich maghemiteis assumed to be essentially related to the wide range of composition and cubic unit cell dimension of its precursor ( $\mathrm{Mg}, \mathrm{Ti})$-rich magnetite, though thesubsequent role, played by fundamental weathering processes involved in the $\mathrm{Fe}^{2+}$ oxidation during pedogenesis on these variations, could not be safely separated and identified.

\section{ACKNOWLEDGMENTS}

Work financially supported by CNPq, FINEP and FAPEMIG (Brazil). CAPES (Brazil) granted a DSC fellowship to W.N. Mussel. We are indebted to Ms Kelen Cristina Lopes Martins (CNPMS/E MBRAPA, Brazil) for the technical support on the crystal separation and some chemical laboratory manipulations; to Ms Maria Beatriz Harmendari Vieira (Vale do Rio Doce Co., Brazil) for the optical microscope analysis and to Dr. Genilson P. Santana (Department of Chemistry, Federal University of Amazonas, Brazil) for some Mössbauer measurements.

To Dr. Derli P. Santana (CNPMS/EMBRAPA) and Professor Nilton Curi (Departamento de Ciências do Solo, UFLA) for their help on the soil sellection and soil sample collection.

\section{LITERATURE CITED}

CARMO, D.N.; CURI, N. \& RESENDE, M. Caracterização e gênese de Latossolos da região do Alto Paranaíba (MG). R. Bras. Ci. Solo, 8:235-240, 1984.

CUGAT, O.; BYRNE, R.; MCCAULEY, J \& \& COEY, J .M.D. A compact vibrating-samplemagnetometer. Rev. Sci. Instrum., 65:3570-3573, 1994.

CURI, N. \& FRANZMEIER, D.P. Toposequense of oxisols from the Central Plateau of Brazil. Soil Sci. Soc. Am. J ., 48:341346, 1984.

FABRIS, J .D.; COEY,J .M.D.; J ESUS FILHO, M.F.; SANTANA, D.P.; GOULART, A.T.; FONTES, M.F. \& CURI, N. Mineral ogical analysis of a weathering mantle derived from tuffite. Hyperfine Interact., 91:751-757, 1994.

FABRIS, J.D.; COEY, J.M.D.; QI, Q. \& MUSSEL, W.N . Characterization of $\mathrm{Mg}$-rich maghemite from tuffite: Am. Mineral., 80:664-669, 1995.

FABRIS, J .D.; MUSSEL, W.N.; COEY, J .M.D.; J ESUS FILHO, M.F. \& GOULART, A.T. Mg-rich iron oxide spinels from tuffite. Hyperfine Interact., 110:33-40, 1997.

FERREIRA, S.A.D.; SANTANA, D.P.; FABRIS, J .D.; CURI, N.; NUNES FILHO, E. \& COEY, J.M.D. Interrelações entre magnetização, elementos traços e litologia de duas seqüências de solos do estado de Minas Gerais. R. Bras. Ci. Solo, 18:167-174, 1994.

GOULART, A.T.; J ESUS FILHO, M.F .; FABRIS, J .D. \& COEY J.M.D. Multiple iron-rich spinel phases and hematite of a magnetic soil developing on tuffite. Phys. Chem. Miner., 25:63-69, 1997.

JEFFERY, P.G. \& HUTCHISON, D. Chemical methods of rock analysis. 3.ed. Oxford, Pergamon Press, 1981. 379p.

MUSSEL, W.W.; COLY, J .M.D. FABRIS, J .D. \& J ESUS FILHO, M.F. Mössbauer study of Mg-doped maghemite. Hyperfine Interactions, 2:53-60, 1997. 